\title{
Synergy of the westerly winds and monsoons in the lake evolution of global closed basins since the Last Glacial Maximum and implications for hydrological change in central Asia
}

\section{Yu Li and Yuxin Zhang}

Key Laboratory of Western China's Environmental Systems (Ministry of Education), College of Earth and Environmental Sciences, Center for Hydrologic Cycle and Water Resources in Arid Region, Lanzhou University, Lanzhou 730000, China

Correspondence: Yu Li (liyu@lzu.edu.cn)

Received: 11 April 2020 - Discussion started: 24 April 2020

Revised: 10 September 2020 - Accepted: 1 October 2020 - Published: 19 November 2020

\begin{abstract}
The monsoon system and westerly circulation, to which climate change responds differently, are two important components of global atmospheric circulation interacting with each other in the middle to low latitudes. Relevant research on global millennial-scale climate change in monsoon and westerly regions is mostly devoted to multiproxy analyses of lakes, stalagmites, ice cores, and marine and eolian sediments. Different responses from these proxies to long-term environmental change make understanding climate change patterns in monsoon and westerly regions difficult. Accordingly, we disaggregated global closed basins into areas governed by monsoon and westerly winds, unified paleoclimate indicators, and added lake models and paleoclimate simulations to emphatically track millennial-scale evolution characteristics and mechanisms of East Asian summer monsoon and westerly winds since the Last Glacial Maximum (LGM). Our results reveal that millennial-scale water balance change exhibits an obvious boundary between global monsoon and westerly regions in closed basins, particularly in the Northern Hemisphere. The effective moisture in most closed basins of the midlatitude Northern Hemisphere mainly exhibits a decreasing trend since the LGM, while that of the low latitudes shows an increasing trend. In the monsoon-dominated closed basins of Asia, a humid climate prevails in the early to mid-Holocene, and a relatively dry climate appears in the LGM and late Holocene. In the westerlywind-dominated closed basins of Asia, the climate is characterized by a humid LGM and mid-Holocene (MH) compared with the dry early and late Holocene, which is likely to be
\end{abstract}

connected to precipitation brought by the westerly circulation. This study provides insight into the long-term evolution and synergy of westerly winds and monsoon systems as well as a basis for the projection of future hydrological balance.

\section{Introduction}

As important components of atmospheric circulation systems, the midlatitude westerly winds and low-latitude monsoon systems play key roles in global climate change. Whether on the decadal or the millennial scale, research on this aspect always attracts widespread attention from scientists. Examination of global monsoon precipitation changes on land suggests an overall weakening over the recent halfcentury (1950-2000) (Zhou et al., 2008). Individual monsoon indexes reconstructed by Wang et al. (2017) indicate that moisture in the tropical Australian, East African, and Indian monsoon regions has exhibited a gradual decrease since the early Holocene. It is widely accepted that the East Asian summer monsoon usually follows the variation of lowlatitude summer solar radiation (Yuan et al., 2004; Chen et al., 2006; An et al., 2015). Charney (1969) and Wang (2009) also proposed that the seasonal migration of the intertropical convergence zone (ITCZ) profoundly influences the seasonality of the global monsoons. However, the global westerly winds and their associated storm tracks dominate the midlatitude dynamics of the global atmosphere and affect extratropical large-scale temperature and precipitation 
patterns (Oster et al., 2015; Voigt et al., 2015). Since the Last Glacial Maximum (LGM), the climate in central and southern regions of the North American continent has gradually dried out as the ice sheet melted and the westerlies moved north (Qin et al., 1997). As mentioned in previous studies, millennial-scale evolution in global monsoons and westerly winds probably shows different patterns as a result of complex driving mechanisms. Arguments about an asynchronous pattern of moisture variations between monsoon and westerly wind evolution underscore the importance of studying their millennial-scale differentiation (Chen et al., 2006, 2008, 2019; An and Chen, 2009; Li et al., 2011; An et al., 2012).

A way to examine past climate variability is traditional methods of studying various archives that truly document the evolution of regional climate, including lake sediments (Madsen et al., 2008), stalagmites (Dykoski et al., 2005; Wang et al., 2008), and tree rings (Linderholm and Braeuning, 2006). However, due to the limited timescale of paleoclimate records, most research on the evolution of monsoons and westerly winds is concentrated in the Holocene and lack an exploration during the LGM. With the development of paleoclimatology in recent decades, numerical simulations of paleoclimate continue to emerge and develop to a relatively mature system, which provides a useful tool for reviewing paleoclimate change over long timescales. On account of the water balance system constantly responding to climatic condition changes, a combination of numerical simulations and lake water balance models can be used to effectively track past climate change and make up the deficiency in qualitative methods of multi-proxy analysis (Qin and Yu, 1998; Xue and Yu, 2000; Morrill et al., 2001, 2004; Li and Morrill, 2010, 2013; Lowry and Morrill, 2019; Li et al., 2020). Covering one-fifth of the terrestrial surface, global closed basins are distributed in both low-latitude monsoon regions and midlatitude westerlies. Furthermore, closed basins with a relatively independent hydrological cycle system have plenty of terminal lake records that provide more evidence for retrospecting climate change (Li et al., 2017), and these can be regarded as ideal regions to study the spatiotemporal difference between monsoons and westerly winds.

By constructing virtual lake systems, here we applied lake models and a transient climate evolution model to continuously simulate water balance change since the LGM in global closed basins. Meanwhile, precipitation minus evaporation $(P-E)$ simulations and 37 lake status records in the LGM, mid-Holocene (MH), and preindustrial (PI) were supplemented to validate results of the continuous simulations. The prominent spatial differentiation of monsoons and westerly winds revealed by simulations leads us to focus on the Northern Hemisphere midlatitude closed basins, which are simultaneously influenced by midlatitude westerly winds and low-latitude monsoons. In the midlatitude closed basins of the Northern Hemisphere, the good match between a water balance simulation and a reconstructed moisture index from 27 paleoclimate records verifies the reliability of the simulation results. Further, we disaggregated the Northern Hemisphere midlatitude closed basins into areas dominated by monsoons and westerly winds and emphatically explored the temporal evolution of the East Asian summer monsoon and westerly winds since the LGM. According to the climate records, we comprehensively considered the determinants that have controlled the trend of climate change in the Northern Hemisphere westerlies and East Asian summer monsoon regions since the LGM. This study not only reveals millennial-scale climate change from the perspective of water balance, but also provides a new method for studying the synergy of the westerly winds and monsoons.

\section{Material and methods}

\subsection{Experimental design}

\subsubsection{Transient climate evolution experiment and CMIP5/PMIP3 multi-model ensemble}

The transient climate evolution experiment (TraCE $21 \mathrm{kyr}$ ), as a synchronously coupled atmosphere-ocean circulation model simulation, is completed by the Community Climate System Model version 3 (CCSM3) (He, 2011). We applied this model to continuously simulate effective moisture change represented by virtual water balance variation since the LGM. Likewise, the CCSM4, CNRM-CM5, FGOALS-g2, GISS-E2-R, MIROC-ESM, MPI-ESM-P, and MRI-CGCM3 models participating in CMIP5/PMIP3 were also used to simulate the relative change in $P-E$ during three particular periods (LGM, MH, PI). Here the PI period, which is considered a typical period of the late Holocene, is mainly used to measure the changes in hydroclimate conditions during the LGM and MH periods relative to the late Holocene, as well as verify the feasibility of the lake models by comparing the lake-level simulations with the lake status records among the three periods. PMIP3 protocols define the boundary conditions of these models, with a few exceptions (Table 1). Precession, obliquity, and eccentricity values are specified according to Berger (1978). $\mathrm{CO}_{2}, \mathrm{CH}_{4}$, and $\mathrm{N}_{2} \mathrm{O}$ values are set on the basis of reconstructions from ice cores (Monnin et al., 2004; Flückiger et al., 1999, 2002). A remnant Laurentide ice sheet in the LGM and a modernday ice sheet configuration in the MH and PI simulations are specified by the ICE-5G reconstruction (Peltier, 2004), while the vegetation is prescribed to modern values. Ice sheet configuration and vegetation distribution are used by the GISS model. LGM radiative forcing changes in the MIROC model and MRI model are the exceptions of the PMIP3 boundary conditions; details are shown in Licciardi et al. (1998) and Lowry and Morrill (2019). 
Table 1. Boundary conditions in CMIP5/PMIP3 simulations at PI, MH, and LGM.

\begin{tabular}{llll}
\hline & Preindustrial & Mid-Holocene & Last Glacial Maximum \\
\hline Eccentricity & 0.016724 & 0.018682 & 0.018994 \\
Obliquity $\left(^{\circ}\right)$ & $23.446^{\circ}$ & $24.105^{\circ}$ & $22.949^{\circ}$ \\
Longitude of perihelion $\left(^{\circ}\right)$ & $102.04^{\circ}$ & $0.87^{\circ}$ & $114.42^{\circ}$ \\
$\mathrm{CO}_{2}(\mathrm{ppm})$ & 280 & 280 & 185 \\
$\mathrm{CH}_{4}(\mathrm{ppb})$ & 760 & 650 & 350 \\
$\mathrm{~N}_{2} \mathrm{O}(\mathrm{ppb})$ & 270 & 270 & 200 \\
Ice sheet & Peltier (2004), 0 ka & Peltier (2004), 0 ka & Peltier (2004), 21 ka \\
Vegetation & Present day & Present day & Present day \\
\hline
\end{tabular}

\subsubsection{Lake energy balance model and lake water balance model}

Before calculating, we linearly interpolated differentresolution grid cells of the TraCE model and multi-model ensemble into a uniform resolution of $0.5^{\circ} \times 0.5^{\circ}$. For all grid cells in closed basins, we assumed that the virtual lake in each grid cell is a $1 \mathrm{~m}$ deep lake with fresh water, and then the virtual lake evaporation is calculated by a lake energy balance model that is modified according to the Hostetler and Bartlein (1990) model. The evaporation of lake surface depends on the heat capacity of water, water density, lake depth, lake surface temperature, shortwave radiation, longwave radiation absorbed by the water surface, longwave radiation emitted by the water surface, latent heat flux, and sensible heat flux. If the surface energy balance is negative (positive), ice forms (melts). Lake depth and lake salinity are important input parameters influencing lake surface evaporation (Dickinson et al., 1965); however, only small changes appear in lake evaporation when adding lake depth to 5 and $10 \mathrm{~m}$ and increasing lake salinity to $10 \mathrm{ppt}$. More details on the lake energy balance model are described in Morrill (2004) and Li and Morrill (2010).

To better assess the relative change in water balance since the LGM, the virtual lakes are assumed to be in hydrological equilibrium at steady state. The lake water balance equation is shown as follows:

$D=A_{\mathrm{B}} R+A_{\mathrm{L}}\left(P_{\mathrm{L}}-E_{\mathrm{L}}\right)$,

where $D$ is discharge from the lake $\left(\mathrm{m}^{3} \mathrm{yr}^{-1}\right), A_{\mathrm{B}}$ is the area of the drainage basin $\left(\mathrm{m}^{2}\right), R$ is runoff from the drainage basin $\left(\mathrm{m} \mathrm{yr}^{-1}\right), A_{\mathrm{L}}$ is the area of the lake $\left(\mathrm{m}^{2}\right), P_{\mathrm{L}}$ is precipitation over the lake $\left(\mathrm{m} \mathrm{yr}^{-1}\right)$, and $E_{\mathrm{L}}$ is lake evaporation $\left(\mathrm{m} \mathrm{yr}^{-1}\right)$. Given the application of Eq. (1), requiring specific values of $A_{\mathrm{B}}$ and $A_{\mathrm{L}}$, this equation is simplified for grid cells wherein $P_{\mathrm{L}}-E_{\mathrm{L}} \geq 0$ and grid cells wherein $P_{\mathrm{L}}-E_{\mathrm{L}}<0$. Grid cells wherein $P_{\mathrm{L}}-E_{\mathrm{L}} \geq 0$ represent open lakes and maintain water balance by discharging more or less water. The runoff into the lake compensates for the net water loss in grid cells wherein $P_{\mathrm{L}}-E_{\mathrm{L}}<0$, and these regions maintain water balance by changes in the ratio of $A_{\mathrm{L}}$ to $A_{\mathrm{B}}$, as described by setting $D=0$ in Eq. (2):

$\frac{A_{\mathrm{L}}}{A_{\mathrm{B}}}=\frac{R}{\left(E_{\mathrm{L}}-P_{\mathrm{L}}\right)}$,

where $A_{\mathrm{L}} / A_{\mathrm{B}}$ represents the virtual lake level. Accordingly, for grid cells with $P_{\mathrm{L}}-E_{\mathrm{L}}<0$, the $A_{\mathrm{L}} / A_{\mathrm{B}}$ values are calculated and compared to represent relative water balance change, and more details about the lake water balance model are described in Li and Morrill (2010). We combined the values of $P_{\mathrm{L}}, E_{\mathrm{L}}$, and $R$ with Eqs. (1) and (2) and simulated the continuous water balance change since the LGM using the TraCE 21 kyr model.

\subsection{Record selection and moisture index inference}

Status information for 37 lakes in or near global closed basins was collected to compare relative changes among the three characteristic periods. Lake status information sorted by latitude is shown in Table 2. Then, 27 climate records were compiled in or near the midlatitude closed basins of the Northern Hemisphere with reliable chronologies and successive sedimentary sequences from published literature, which can reflect the continuous dry and wet change (Table 3 ). We interpolated climate data at intervals of 10 years and unified the timescale according to the chronological accuracy of the extracted data. Finally, the data were standardized to indicate a humid climate with a relatively high value and a dry climate with a relatively low value, and the signals of moisture change were transformed into an index range of 0 to 1 . Due to the different timescales of the collected continuous paleoclimate records, we can only reconstruct the regional moisture change from the early to late Holocene after unifying the timescales, but the purpose of this part is only to check the simulation results.

\subsection{Mathematical methods}

Linear tendency estimation is a common trend analysis method, which was chosen to measure the variation degree of simulated water balance in this paper. We also used the empirical orthogonal function (EOF), a method of analyzing the structural features in matrix data and extracting the feature 


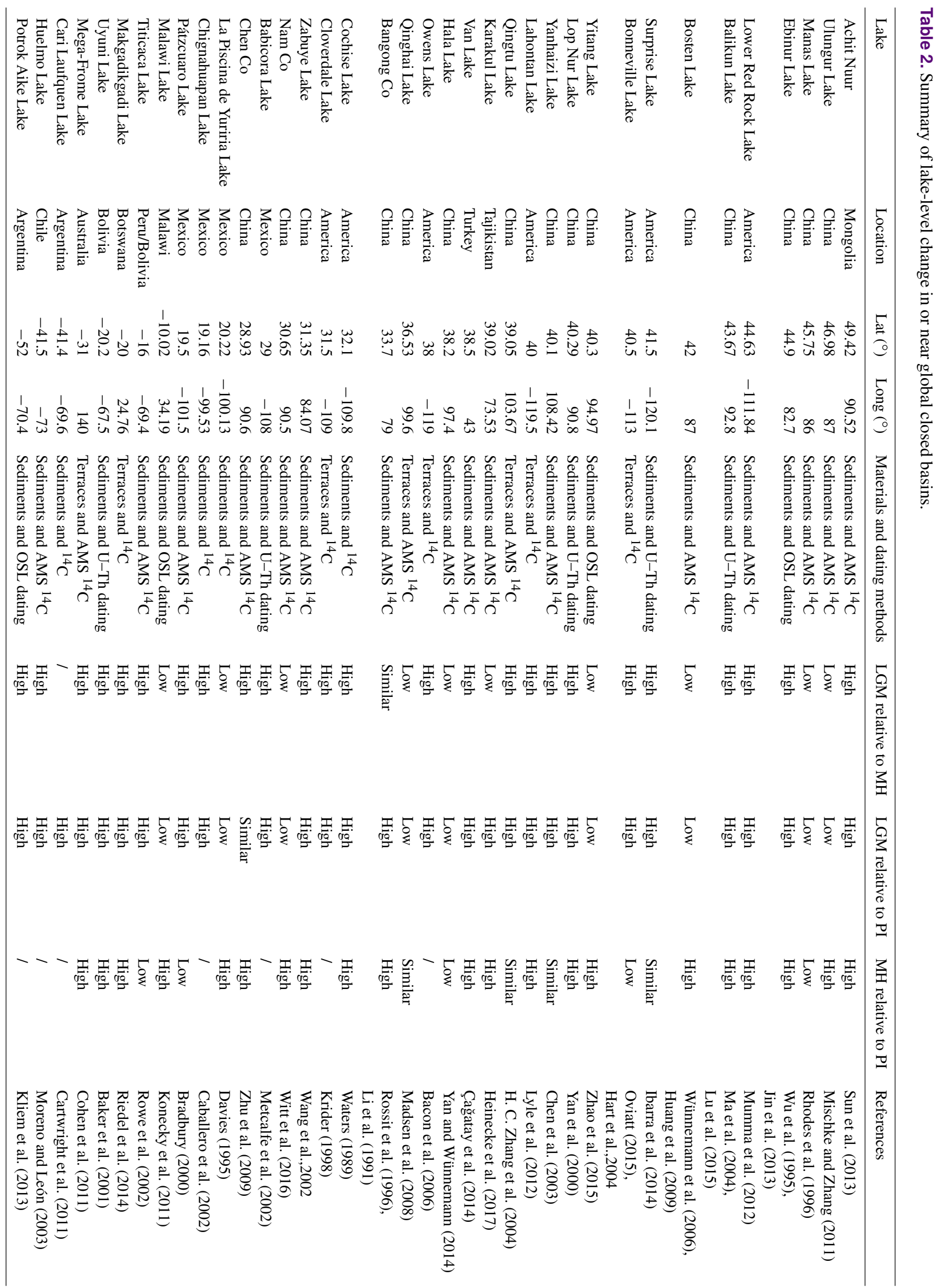




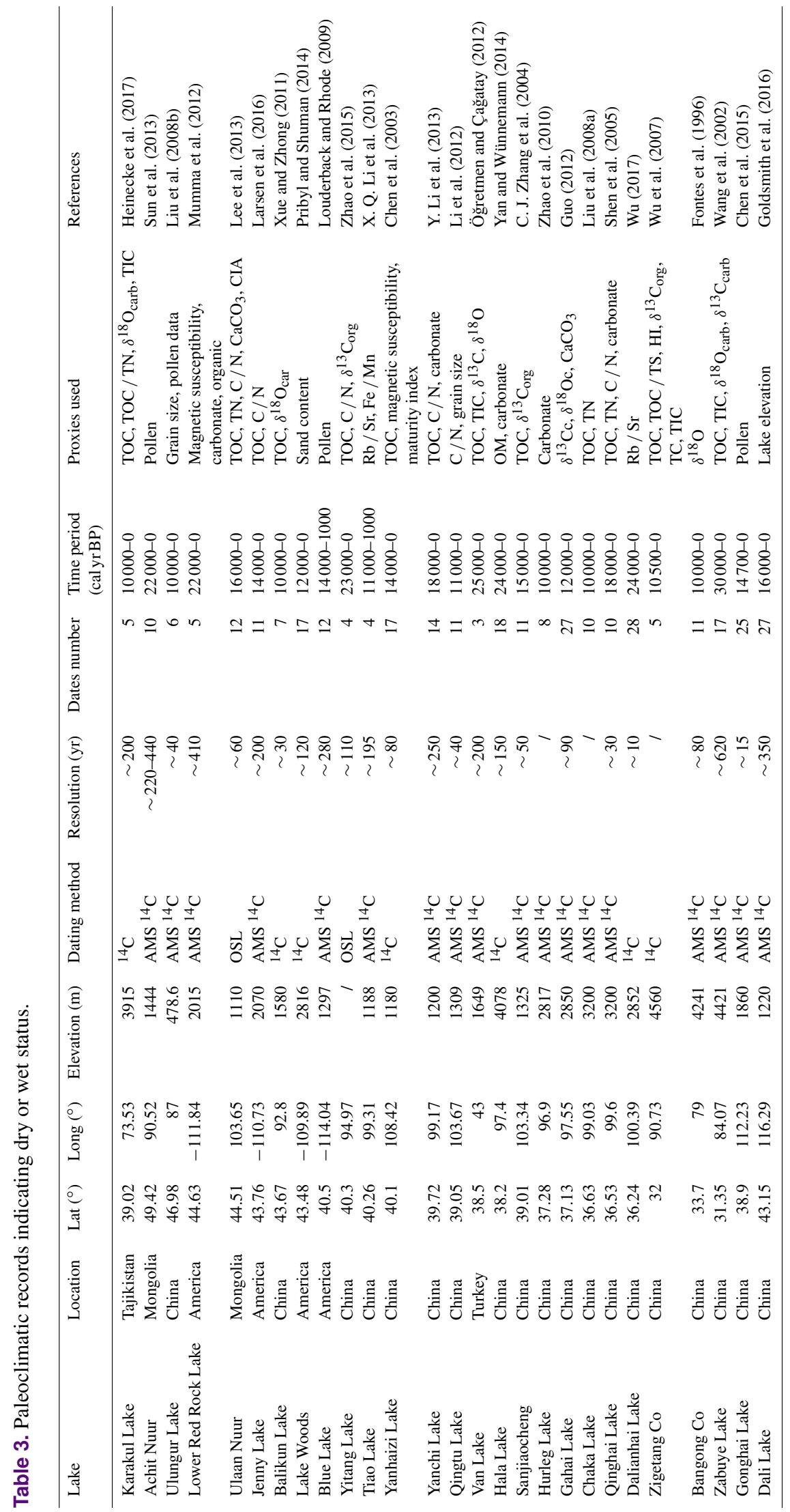


vector of main data to examine the spatial and temporal variability of simulated water balance. The spatial distribution of the EOF first (second) mode is denoted by EOF1 (EOF2), and the time series of the first (second) mode is denoted by PCA1 (PCA2).

\section{Results and discussion}

\subsection{Observed and simulated water balance change in global closed basins}

As Fig. 1 shows, we intercepted LGM (18 000-22 000 yr), MH (5000-7000 yr), and PI (1800-1900 AD) periods from the TraCE 21 kyr dataset to better match the multi-model ensemble. Because runoff anomalies are highly correlated with precipitation anomalies, it is therefore feasible to consider the contribution of runoff to the water balance to be the contribution of precipitation to the water balance. Differences between the time period we chose subjectively and the time periods defined by the multi-model ensemble may affect the comparison results. However, the precipitation and evaporation difference of TraCE $21 \mathrm{kyr}$ among the three periods exhibits a similar spatial pattern as the $P-E$ difference of the multi-model ensemble. The simulations and lake status records of the midlatitude westerlies (low-latitude monsoon regions) show that the LGM is humid (dry) relative to $\mathrm{MH}$ and PI, which generally corresponds to the hydroclimate patterns of previous research (Street and Grove, 1979; Qin et al., 1997; Quade and Broecker, 2009; Lowry and Morrill, 2019). It is not our intent to simulate relative lake status change among the three periods, but to validate continuous water balance simulations and to track continuous water balance fluctuations on the millennial scale using TraCE $21 \mathrm{kyr}$ simulations.

In continuous simulations, we partitioned the trend map of water balance into positive and negative components to highlight the spatial patterns of water balance change (Fig. 2). In the global midlatitude westerlies, simulations indicate that widespread effective moisture has declined since the LGM except in the northern Caspian Sea, whereas effective moisture has increased since the LGM over the global tropics. Meanwhile, the trend map exactly exhibits the spatial differentiation of the millennial-scale water balance change between the global low-latitude monsoon-dominated regions and the midlatitude westerly-wind-dominated regions. This differentiation provides the basis to explore the continuous evolution of monsoons and westerly winds in closed basins since the LGM.

\subsection{Possible driving mechanisms of millennial-scale water balance change}

In this section, the possible driving mechanism that affects the millennial-scale water balance change in global closed basins is explored. Positive signs of EOF1 represent most monsoon regions in the midlatitudes and low latitudes, while negative signs are mainly located in the Northern and Southern Hemisphere westerlies. Spatial characteristics of EOF2 have an opposite trend to EOF1, except for the Caspian Sea. The contribution rate of PCA1 and PCA2 is $51 \%$ and $14 \%$, respectively; therefore, the following discussion mainly focuses on PCA1 with a high contribution rate (Fig. 3). PCA1 extracted from the water balance simulation tends to represent the effective moisture fluctuation of closed basins in low-latitude monsoon regions, indicating a relatively humid climate during the early to mid-Holocene. By comprehensively analyzing a variety of paleoclimate proxies, Wang et al. (2017) suggested that moisture change revealed by the Australian monsoon, the East African monsoon, and the Indian monsoon regions reaches the wettest status in the early Holocene, while the wettest condition in the East Asian summer monsoon regions occurs between 8 and $6 \mathrm{ka}$. Likewise, Qin et al. (1997) presented the wettest period in the African and South Asian monsoon regions as the early to mid-Holocene, coinciding well with our results.

The climatic significance of $\delta^{18} \mathrm{O}$ in the Asian speleothem records is always a long-standing debate, and some influential hypotheses regard $\delta^{18} \mathrm{O}$ of the monsoon regions as a proxy for "Asian monsoon intensity", "Indian monsoon intensity", "summer monsoon rainfall amount", and "circulation conditions" (Cheng et al., 2012; Chen et al., 2016). Although the climatic significance is controversial, it is well accepted that $\delta^{18} \mathrm{O}$ changes should bear the imprint of variations in the oxygen isotopic composition of precipitation (Cheng et al., 2012; Chen et al., 2016). According to the close similarity of PCA1 to the speleothem records from Dongge and Hulu caves, our simulations are more inclined to suggest that the $\delta^{18} \mathrm{O}$ stalagmite records indicate a change in water vapor brought by the monsoons. In addition, we not only compared PCA 1 to the stalagmite records of Dongge Cave, with controversial climatic significance, but also with the summer solar radiation at low latitudes in the Northern Hemisphere. This comparison provides evidence for the view that the evolution of low-latitude monsoons is generally controlled by summer insolation in the Northern Hemisphere (Yuan et al., 2004; Chen et al., 2006; An et al., 2015). Thus, we further speculated that the water balance change in monsoon regions of global closed basins is mainly driven by midlatitude and low-latitude summer solar radiation.

\subsection{Evolutionary characteristics and causal factors of millennial-scale hydroclimate change in Northern Hemisphere midlatitude closed basins}

On the basis of the spatial characteristics of the EOF analysis, closed basins in the Northern Hemisphere, affected both by low-latitude monsoons and midlatitude westerly winds, are ideal regions for revealing the synergy of the westerly winds and monsoons. Between $30^{\circ}$ and $60^{\circ} \mathrm{N}, 27$ paleoclimate records indicating dry or wet climate were collected 
LGM-MH

LGM-PI

MH-PI

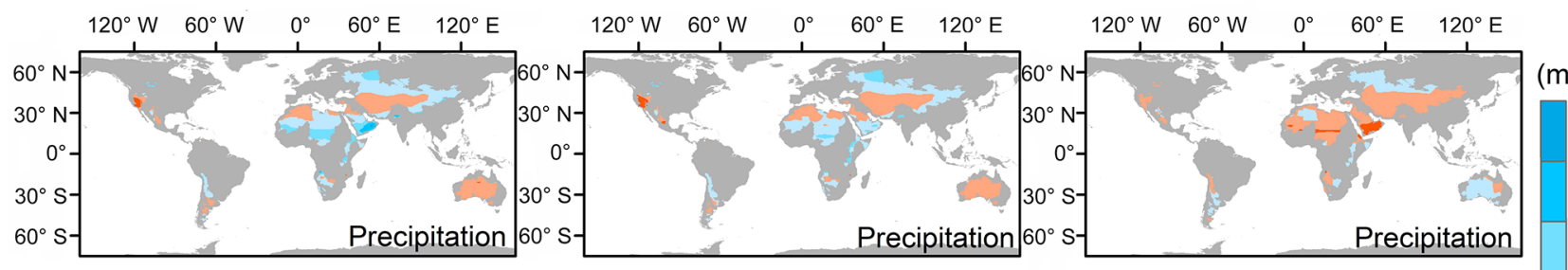

$(\mathrm{mm})$

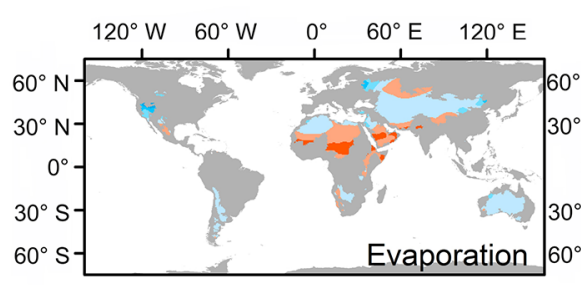

$120^{\circ} \mathrm{W} \quad 60^{\circ} \mathrm{W} \quad 0^{\circ} \quad 60^{\circ} \mathrm{E} \quad 120^{\circ} \mathrm{E}$
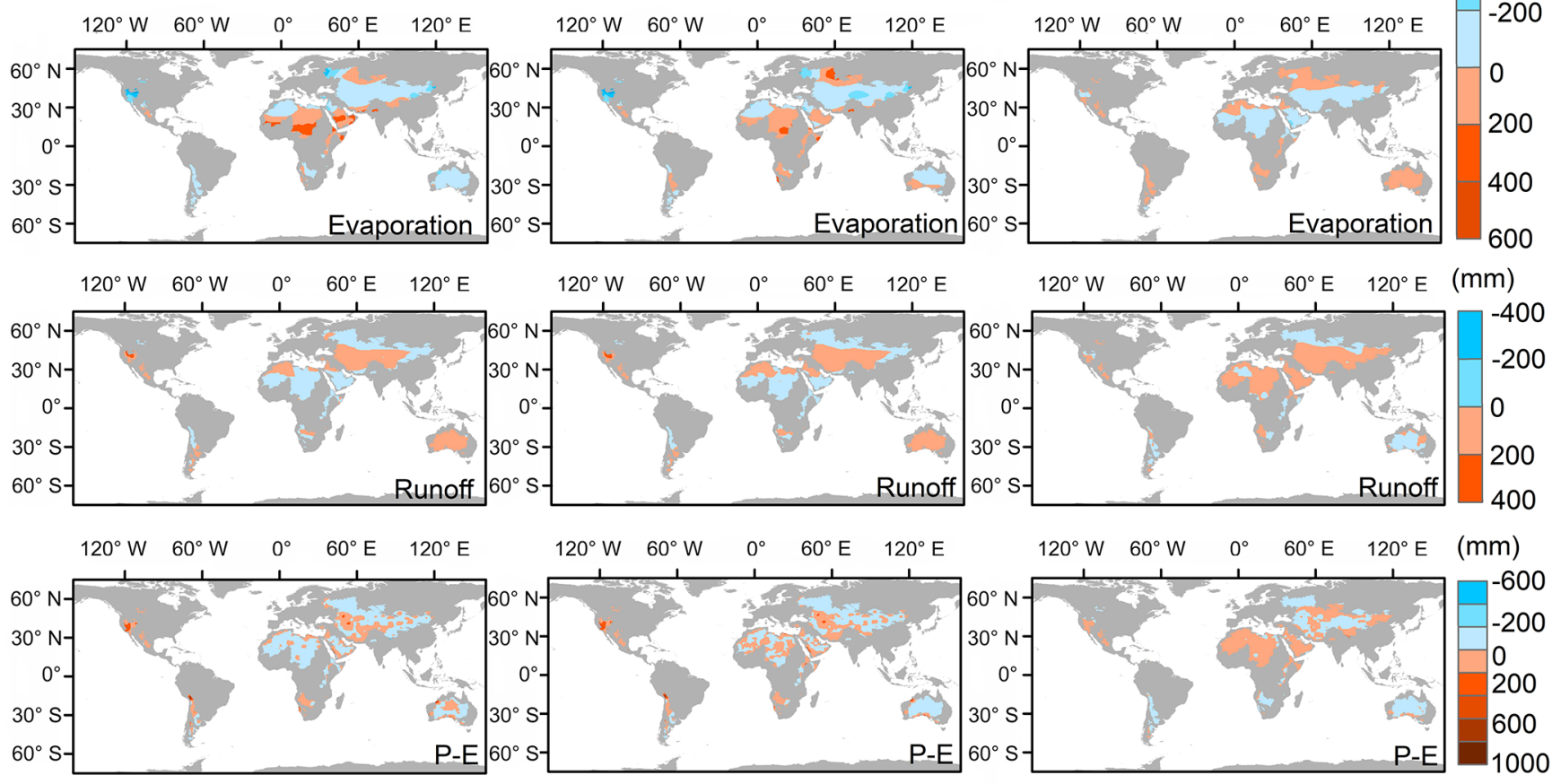

Figure 1. Annual mean precipitation, evaporation, and runoff from TraCE $21 \mathrm{kyr}$ simulations, as well as precipitation minus evaporation $(P-E)$ from the multi-model ensemble (units: $\mathrm{mm} \mathrm{yr}^{-1}$ ); (first column) difference between LGM and MH simulations; (second column) difference between LGM and PI simulations; (third row) difference between MH and PI simulations.

from the Northern Hemisphere midlatitude closed basins. As described in Sect. 2.2, we reconstructed a moisture index from the early to late Holocene around that region (Fig. 4). The simulated mean water balance curve corresponds well to the mean moisture index in the Northern Hemisphere midlatitude closed basins, indicating a transition from a humid climate in the early to mid-Holocene to an arid climate in the late Holocene. Therefore, continuous simulations, well validated by paleoclimate indicators, could be better used to track climate change during the LGM.

Water balance simulations since the LGM show that a humid climate not only appears in the early to mid-Holocene but also occurs during the LGM, while the climate is relatively dry in the late Holocene. The maintained high moisture in the LGM is possibly influenced by low evaporation and high precipitation (Fig. 5). Using paleoclimate modeling, Yu et al. (2000) mentioned that the low temperature during the glacial period causes a decrease in evaporation and a reduction of lake water loss, resulting in the appearance of a high lake level. Afterward, solar radiation, atmosphere radiation, temperature, evaporation, and precipitation simulations gradually increase (Fig. 5). When entering the warm Holocene, precipitation continues to increase and reaches a maximum in the $\mathrm{MH}$, while solar radiation, atmospheric radiation, and evaporation decrease during the early to mid-Holocene and then increase around the late Holocene. Low (high) evaporation and high (low) precipitation are responsible for the $\mathrm{MH}$ (late Holocene) relatively humid (dry) climate (Fig. 5).

\subsection{Evolutionary differentiation of millennial-scale monsoons and westerly winds in Asian closed basins}

Spatial distributions of EOF1 and EOF2 clearly exhibit a prominent boundary in the interactional zones between the East Asian summer monsoon and westerly winds in Asia. Since the boundary of the monsoon will be adjusted accordingly with the change in the East Asian summer monsoon strength, the evolution of Asian lakes on the millennial scale probably does not follow a single climate changing pattern 

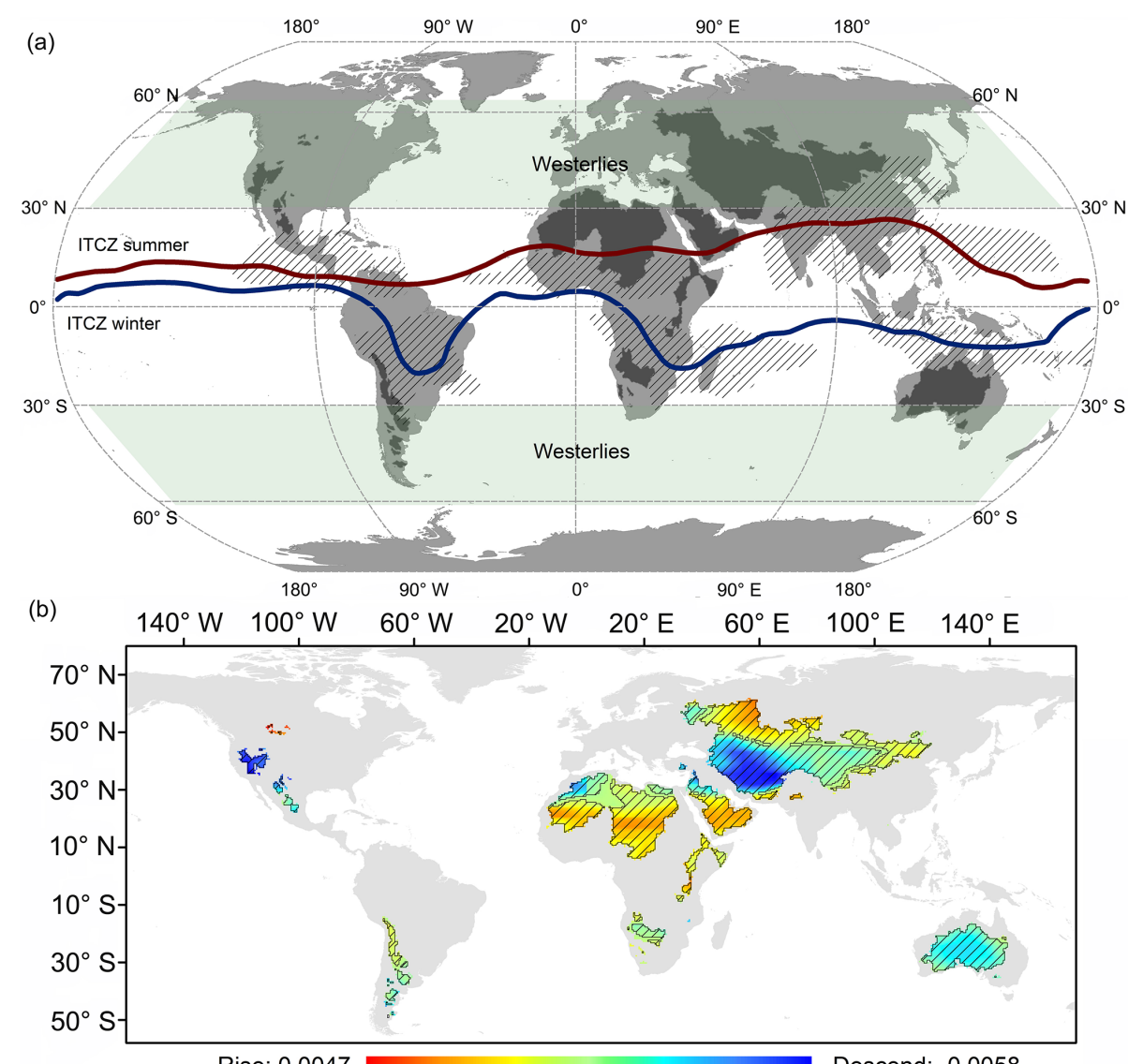

Rise: 0.0047

Figure 2. (a) Distribution of global closed basins and circulation system: the dark areas are global closed basins; summer and winter in the ITCZ are in accordance with the Northern Hemisphere. The shading represents the six monsoon areas according to Wang (2009). (b) Trend analysis of continuous simulation in water balance change: the shading indicates that the trends are statistically significant at the $5 \%$ level.
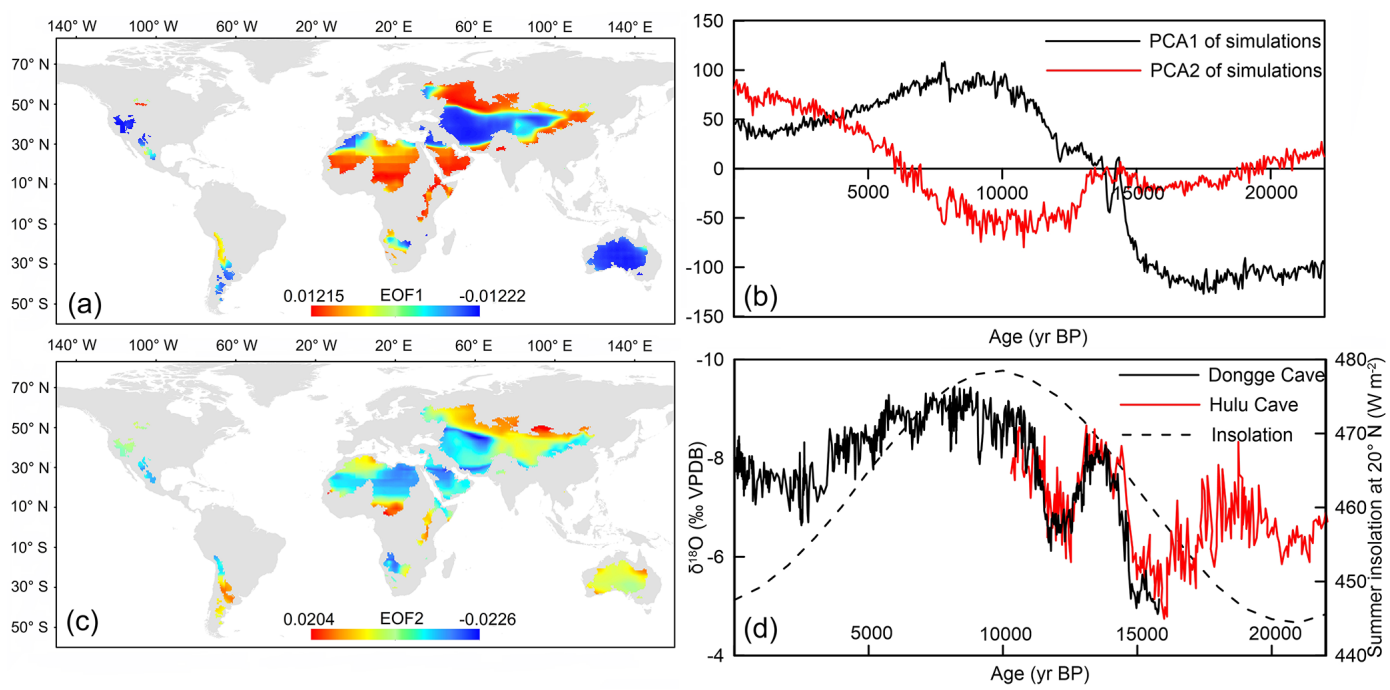

Figure 3. (a) Spatial distribution feature of EOF1, (b) PCA1, and PCA2 of simulated water balance change since the LGM. (c) Spatial distribution feature of EOF2. (d) Comparison between stalagmite records and summer insolation: stalagmite records come from Dykoski et al. (2005) and Wang et al. (2008), and summer insolation comes from Berger (1978). 


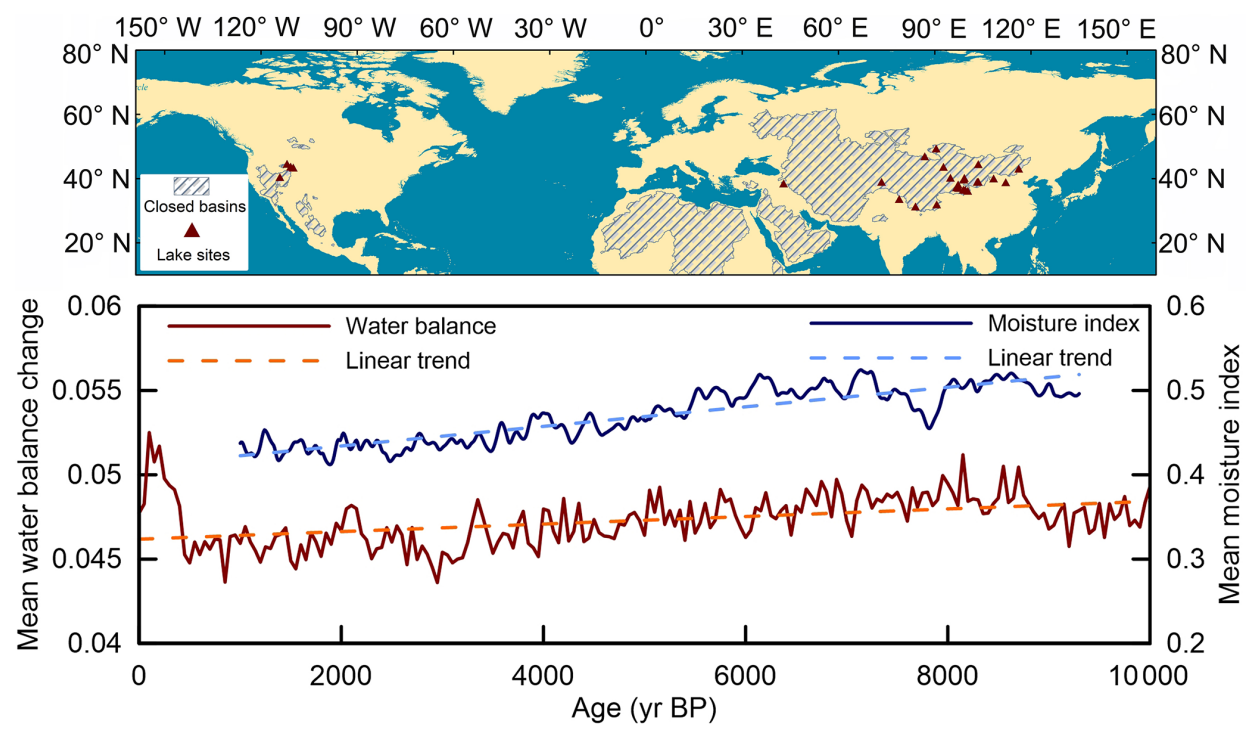

Figure 4. Comparison between simulated water balance change and reconstructed moisture index in the midlatitude closed basins of the Northern Hemisphere during the Holocene. Triangles indicate locations of paleoclimate records (Table 3 ).

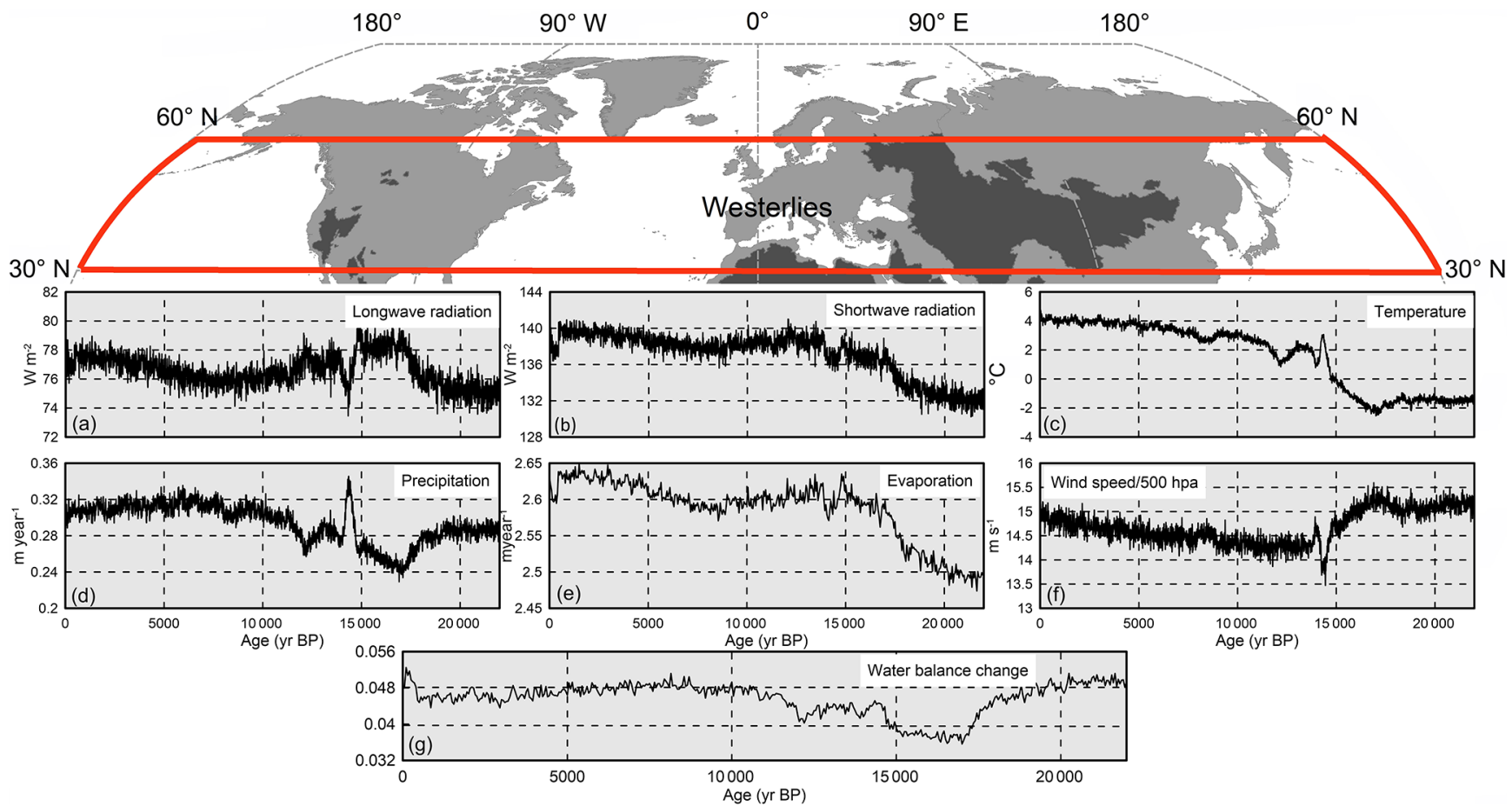

Figure 5. Time series of (a) longwave radiation, (b) shortwave radiation, (c) temperature, (d) precipitation, (e) evaporation, (f) 500 hpa wind speed, and (g) water balance change between $30^{\circ}$ and $60^{\circ} \mathrm{N}$ in closed basins since the LGM.

(Wu and Guo, 2000; Editorial Committee of China's Physical Geography, 1984; An et al., 2012). The regions dominated by the East Asian summer monsoon and westerly winds were then selected based on the spatial characteristics of the two modes extracted from the EOF to explore millennialscale evolution features of the two climate systems (Fig. 6). In westerly-wind-dominated regions, the LGM and $\mathrm{MH}$ are characterized by a humid climate, and a relatively dry climate prevails in the early and late Holocene, whereas the water balance in monsoon-dominated regions is generally affected by the East Asian summer monsoon, which brought a lot of water vapor over the early to mid-Holocene and led to a relatively dry climate in the LGM and late Holocene. Li (1990) first proposed the "monsoon" and "westerly" modes 


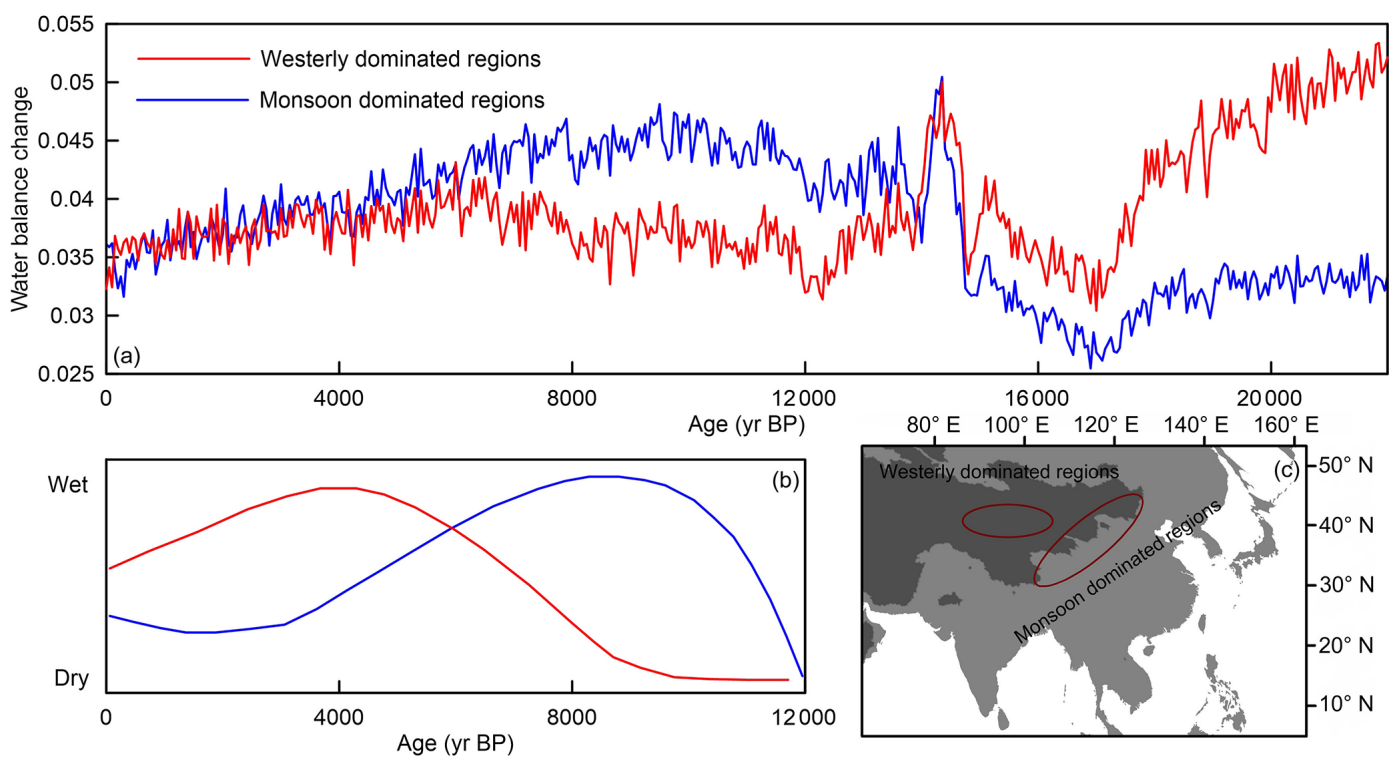

Figure 6. (a) Simulated water balance change between westerly-wind-dominated regions and monsoon-dominated regions in Asian closed basins since the LGM. (b) General climate changing patterns during the Holocene in monsoon Asia and westerly central Asia come from Chen et al. (2006). (c) Extracted westerly-wind-dominated regions and monsoon-dominated regions in Asian closed basins.

on the millennial scale since the late Pleistocene in northwest China; since then different climate changing patterns between arid central Asia and monsoonal Asia have been demonstrated by numerous paleoclimate records (Chen et al., 2006, 2008; An and Chen, 2009; Li et al., 2011; Chen et al., 2019). The viewpoint that millennial-scale East Asian summer monsoon change is possibly driven by summer insolation change in low latitudes is the most widely accepted (Yuan et al., 2004; Dykoski et al., 2005; Hu et al., 2008; Fleitmann et al., 2003); the sea surface temperatures (SSTs) of the North Atlantic and air temperatures at high latitudes are responsible for the Holocene effective moisture evolution in arid central Asia, which is dominated by the westerly winds (Chen et al., 2008). Moisture transport in arid central Asia mainly comes from the Northern Hemisphere westerlies, the moisture source of which derives from the Black Sea, the Mediterranean Sea, the Arctic Ocean, and the Atlantic Ocean. Winter precipitation accounts for a large proportion of annual precipitation in these regions ( $\mathrm{Li}$ et al., 2008).

The water balance change in the Asian monsoon regions we extracted largely represents the hydroclimate variation in regions dominated by the East Asian summer monsoon since the LGM, while the water balance change in the westerly regions in central Asia can represent the hydroclimate variation in the entire Northern Hemisphere westerlies. Qin et al. (1997) made a large-scale spatial analysis and presented lake levels in south-central North America changing from high to low since the LGM, reaching the lowest levels in the early to mid-Holocene. The LGM proxies indicate that southwestern America experienced a climate that was wetter than present, and the Pacific Northwest through the Rockies experienced a climate that was drier than present, as well as a transition from wetter to drier conditions along a northwest-southeast-trending band across the northern Great Basin (Oster et al., 2015). Our results generally reflect the climate of the westerlies being relatively wet at the LGM and relatively dry at the MH. For the Asian tropics in the Northern Hemisphere, the increased summer solar radiation from the past 12000 to the past 6000 years ago induced the enhancement of a thermal contrast between the land and sea and further caused the strengthening of summer monsoons so that more water vapor was brought (COHMAP Members, 1988). Collected records in the Northern Hemisphere indicate the evolution of westerly winds and monsoon systems (Fig. 7). Speleothem records from central and southern China confirm that the periods of weak East Asian summer monsoons coincide with cold periods in the North Atlantic (Yuan et al., 2004, Dykoski et al., 2005; Wang et al., 2008). The longest and highest-resolution drill core from Lake Qinghai (An et al., 2012) indicates that the summer monsoon record generally resembles the changing trends of Asian summer monsoon records derived from Dongge and Hulu speleothems over the last $20 \mathrm{kyr}$, and the midlatitude westerly climate dominates the Lake Qinghai area in glacial times. Low-latitude summer insolation is broadly recognized as a major control on low-latitude monsoon systems; as a result, the tropical monsoons are weak during the LGM and late Holocene, and strong monsoons prevail in the early to mid-Holocene (Fig. 7). Accordingly, the intensity of monsoon systems and westerly winds varies in different periods so that the main control system in the interactional regions 


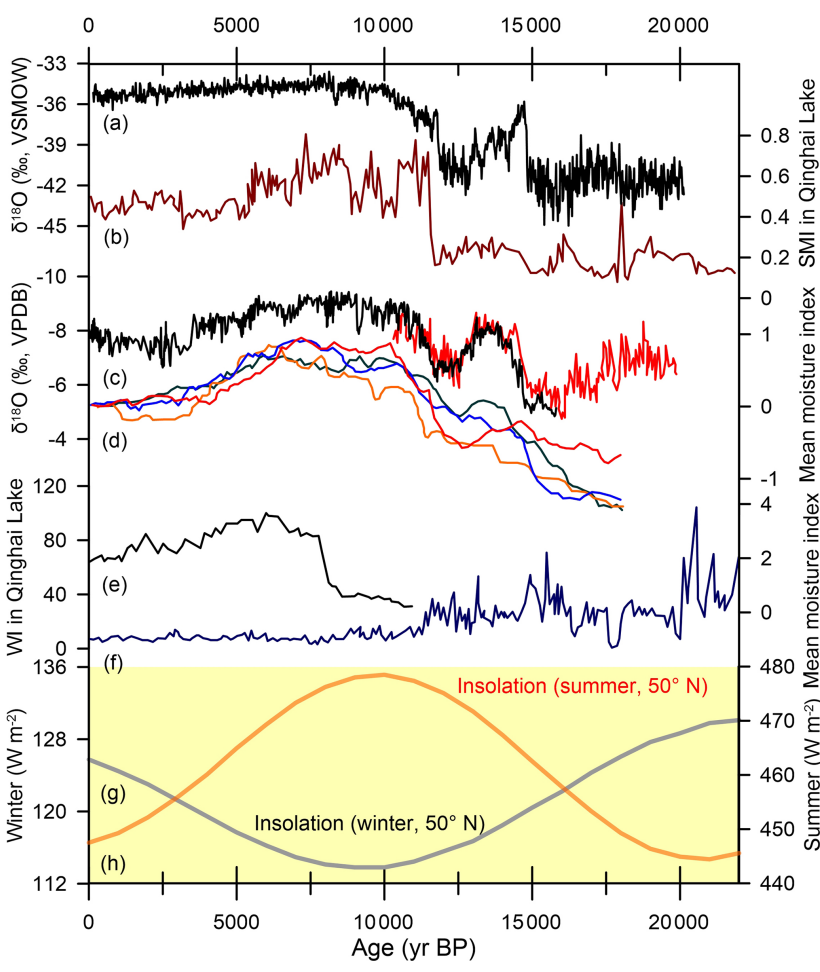

Figure 7. Comparison of records between the westerly and monsoon regions of the Northern Hemisphere. (a) NGRIP $\delta^{18} \mathrm{O}$ (Rasmussen et al., 2006). (b) Lake Qinghai Asian summer monsoon index (An et al., 2012). (c) Dongge and Hulu Cave speleothem $\delta^{18} \mathrm{O}$ records (Dykoski et al., 2005; Wang et al., 2008). (d) Moisture indexes in the East Asian monsoon (red line), East African monsoon (green line), Indian monsoon (blue line), and Australian monsoon (orange line) regions (Wang et al., 2017). (e) The average moisture index for the arid central Asian region as a whole during the Holocene (An and Chen, 2009). (f) Lake Qinghai westerly climate index (An et al., 2012); panels (g, h) show winter $50^{\circ} \mathrm{N}$ insolation and summer $50^{\circ} \mathrm{N}$ insolation, respectively (Berger, 1978).

depends largely on which system is much stronger during that period.

The Northern Hemisphere westerlies shifting northward or southward has a significant impact on global atmosphere circulation and inevitably affects the monsoon systems. Quaternary ice sheets of the Northern Hemisphere in the LGM developed to their maximum extension, and the consequent existence of a persistent strong glacial anticyclone led to the southward displacement of the westerly winds (Yu et al., 2000). Most research suggests that the Northern Hemisphere westerlies in the LGM moved to the southwest of the United States and the eastern Mediterranean region (Lachniet et al., 2014; Rambeau, 2010). Therefore, the narrowed temperature difference between the sea and land caused the East Asian summer monsoon to weaken and may have further induced strong westerly winds throughout the year and then precipitation increases (Yu et al., 2000). Furthermore, a growing body of evidence shows that the position and orientation of the westerly jet (WJ) probably controlled the Holocene East Asian summer rainfall patterns. A link between the northward seasonal progression of the WJ and the spatial pattern of East Asian summer monsoon precipitation shows that earlier northward progression of the WJ caused abundant precipitation at high latitudes and less precipitation at low latitudes (Nagashima et al., 2013). The northward evolution of the WJ from south of the Tibetan Plateau and seasonal transition exerted especially strong influences on East Asian paleoclimate change (Chiang et al., 2015). Herzschuh et al. (2019) proposed that the position of the summer monsoon rain band changed as the $\mathrm{WJ}$ axis shifted gradually southward, leading to the occurrence of a spatiotemporal difference in Holocene China's maximum precipitation. In summary, the above views emphasize that the complex interaction between the monsoon and the westerly systems on the millennial scale should receive more attention.

\section{Conclusions}

On the basis of 37 lake status records near global closed basins and 27 paleoclimatic records near midlatitude closed basins of the Northern Hemisphere, we applied a lake energy balance model, a lake water balance model, and paleoclimate simulations to explore the millennial-scale differentiation between global monsoons and westerly winds. A water balance simulation shows that the effective moisture in most closed basins of the Northern Hemisphere midlatitudes has gradually decreased since the LGM, which matches the reconstructed moisture index well. Effective moisture change in most closed basins of the low latitudes (monsoon regions) presents an opposite changing trend to that in the midlatitudes. In Asian midlatitude closed basins, climate change in regions dominated by westerly winds exhibits a relatively humid climate in the LGM and MH and a relatively dry climate in the early and late Holocene, whereas the East Asian summer monsoon generally influences climate change in closed basins dominated by monsoons, which brought more water vapor over the early to mid-Holocene but less water vapor in the LGM and late Holocene.

Data availability. The TraCE 21 kyr dataset comes from the Climate Data Gateway National Center for Atmospheric Research (NCAR) website at https://www.earthsystemgrid.org/project/trace. html (last access: 6 November 2020, NCAR, 2020). PMIP3/CMIP5 simulations are available from the Earth System Grid Federation (ESGF) Peer-to-Peer (P2P) enterprise system website at https: //esgf-node.llnl.gov/projects/esgf-1lnl/ (last access: 6 November 2020, Lawrence Livermore National Laboratory, 2020). Global closed basin boundaries are derived from hydrological data and maps based on the SHuttle Elevation Derivatives at multiple Scales (HydroSHEDS) website: https://www.hydrosheds.org/page/ hydrobasins (last access: 6 November 2020; WWF, 2020). 
Author contributions. YL and YZ designed this study and carried it out.

Competing interests. The authors declare that they have no conflict of interest.

Acknowledgements. We acknowledge Julie Loisel and two anonymous referees for constructive comments.

Financial support. This research has been supported by the Second Tibetan Plateau Scientific Expedition and Research Program (STEP) (grant no. 2019QZKK0202), the National Natural Science Foundation of China (grant nos. 42077415 and 41822708), and the Strategic Priority Research Program of the Chinese Academy of Sciences (grant no. XDA20100102).

Review statement. This paper was edited by Julie Loisel and reviewed by two anonymous referees.

\section{References}

An, C. B. and Chen, F. H.: The pattern of Holocene climate change in the arid central Asia: a case study based on lakes, Journal of Lake Sciences, 21, 329-334, https://doi.org/10.18307/2009.0303, 2009.

An, Z. S., Colman, S. M., Zhou, W. J., Li, X. Q., Brown, E. T., Jull, A. J. T., Cai, Y. J., Huang, Y. S., Lu, X. F., Chang, H., Song, Y. G., Sun, Y. B., Xu, H., Liu, W. G., Jin, Z. D., Liu, X. D., Cheng, P., Liu, Y., Ai, L., Li, X. Z., Liu, X. J., Yan, L. B., Shi, Z. G., Wang, X. L., Wu, F., Qiang, X. K., Dong, J. B., Lu, F. Y., and $\mathrm{Xu}, \mathrm{X}$. W.: Interplay between the Westerlies and Asian monsoon recorded in Lake Qinghai sediments since $32 \mathrm{ka}$, Sci. Rep.-UK, 2, 619, https://doi.org/10.1038/srep00619, 2012.

An, Z. S., Wu, G. X., Li, J. P., Sun, Y. B., Liu, Y. M., Zhou, W. J., Cai, Y. J., Duan, A. M., Li, L., Mao, J. Y., Cheng, H., Shi, Z. G., Tan, L. C., Yan, H., Ao, H., Chang, H., and Feng, J.: Global Monsoon Dynamics and Climate Change, Annu. Rev. Earth Pl. Sc., 43, 2.1-2.49, https://doi.org/10.1146/annurev-earth-060313054623, 2015.

Bacon, S. N., Burke, R. M., Pezzopane, S. K., and Jayko, A. S.: Last glacial maximum and Holocene lake levels of Owens Lake, eastern California, USA, Quaternary Sci. Rev., 25, 1264-1282, https://doi.org/10.1016/j.quascirev.2005.10.014, 2006.

Baker, P. A., Rigsby, C. A., Seltzer, G. O., Fritz, S. C., Lowenstein, T. K., Bacher, N. P., and Veliz, C.: Tropical climate changes at millennial and orbital timescales on the Bolivian Altiplano, Nature, 409, 698-701, https://doi.org/10.1038/35055524, 2001.

Berger, A. L.: Long-term variations of caloric insolation resulting from the Earth's orbital elements, Quaternary Res., 9, 139-167, https://doi.org/10.1016/0033-5894(78)90064-9, 1978.

Bradbury, J. P.: Limnologic history of Lago de Pátzcuaro, Michoacán, Mexico for the past 48,000 years: impacts of climate and man, Palaeogeogr. Palaeocl., 163, 69-95, https://doi.org/10.1016/S0031-0182(00)00146-2, 2000.
Caballero, M., Ortega, B., Valadez, F., Metcalfe, S., Macias, J. L., and Suguira, Y.: Sta. Cruz Atizapán: A 22-ka lake level record and climatic implications for the late Holocene human occupation in the Upper Lerma Basin, Central Mexico, Palaeogeogr. Palaeocl., 186, 217-235, https://doi.org/10.1016/S00310182(02)00502-3, 2002.

Çağatay, M. N., Öğretmen, N., Damcı, E., Stockhecke, M., Sancar, Ü., Eriş, K. K., and Özeren, S.: Lake level and climate records of the last $90 \mathrm{ka}$ from the Northern Basin of Lake Van, eastern Turkey, Quaternary Sci. Rev., 104, 97-116, https://doi.org/10.1016/j.quascirev.2014.09.027, 2014.

Cartwright, A., Quade, J., Stine, S., Adams, K. D., Broecker, W., and Cheng, H.: Chronostratigraphy and lake-level changes of Laguna Cari-Laufquén, Río Negro, Argentina, Quaternary Res., 76, 430-440, https://doi.org/10.1016/j.yqres.2011.07.002, 2011.

Charney, J. G.: The intertropical convergence zone and the Hadley circulation of the atmosphere, in: Proceedings of the WMO/IUGG Symposium on Numerical Weather Prediction in Tokyo, 26 November-4 December 1968, Jpn. Meteorol. Agency, Tokyo, 73-79, 1969.

Chen, C. T. A., Lan, H. C., Lou, J. Y., and Chen, Y. C.: The Dry Holocene Megathermal in Inner Mongolia, Palaeogeogr. Palaeocl., 193, 181-200, https://doi.org/10.1016/s00310182(03)00225-6, 2003.

Chen, F. H., Huang, X. Z., Yang, M. L., Yang, X. L., Fan, Y. X., and Zhao, H.: Westerly dominated Holocene climate model in arid central Asia-Case study on Bosten lake, Xinjiang, China, Quaternary Science, 26, 881-887, https://doi.org/10.3321/j.issn:1001-7410.2006.06.001, 2006.

Chen, F. H., Yu, Z. C., Yang, M. L., Ito, E., Wang, S. M., Madsen, D. B., Huang, X. Z., Zhao, Y., Sato, T., Birks, H. J. B., Boomer, I., Chen, J. H., An, C. B., and Wünnemann, B.: Holocene moisture evolution in arid central Asia and its out-of-phase relationship with Asian monsoon history, Quaternary Sci. Rev., 27, 351-364, https://doi.org/10.1016/j.quascirev.2007.10.017, 2008.

Chen, F. H., Xu, Q. H., Chen, J. H., Birks, H. J. B., Liu, J. B., Zhang, S. R., Jin, L. Y., An, C. B., Telford, R. J., Cao, X. Y., Wang, Z. L., Zhang, X. J., Selvaraj, K., Lu, H. Y., Li, Y. C., Zheng, Z., Wang, H. P., Zhou, A. F., Dong, G. H., Zhang, J. W., Huang, X. Z., Bloemendal, J., and Rao, Z. G.: East Asian summer monsoon precipitation variability since the last deglaciation, Sci. Rep.-UK, 5, 11186, https://doi.org/10.1038/srep11186, 2015.

Chen, F. H., Chen, J. H., Huang, W., Chen, S. Q., Huang, X. Z., Jin, L. Y., Jia, J., Zhang, X. J., An, C. B., Zhang, J. W., Zhao, Y., Yu, Z. C., Zhang, R. H., Liu, J. B., Zhou, A. F., and Feng, S.: Westerlies Asia and monsoonal Asia: Spatiotemporal differences in climate change and possible mechanisms on decadal to sub-orbital timescales, Earth-Sci. Rev., 192, 337-354, https://doi.org/10.1016/j.earscirev.2019.03.005, 2019.

Chen, J. H., Rao, Z. G., Liu, J. B., Huang, W., Feng, S., Dong, G. H., Hu, Y., Xu, Q. H., and Chen, F. H.: On the timing of the East Asian summer monsoon maximum during the Holocene - Does the speleothem oxygen isotope record reflect monsoon rainfall variability?, Sci. China Earth Sci., 59, 2328-2338, https://doi.org/10.1007/s11430-015-5500-5, 2016.

Cheng, H., Sinha, A., Wang, X., Cruz, F. W., and Edwards, R. L.: The global paleomonsoon as seen through speleothem records from Asia and the Americas, Clim. Dynam., 39, 1045-1062, https://doi.org/10.1007/s00382-012-1363-7, 2012. 
Chiang, J. C. H., Fung, I. Y., Wu, C. H., Cai, Y. J., Edman, J. P., Liu, Y. W., Day, J. A., Bhattacharya, T., Mondal, Y., and Labrousse, C. A.: Role of seasonal transitions and westerly jets in East Asian paleoclimate, Quaternary Sci. Rev., 108, 111-129, https://doi.org/10.1016/j.quascirev.2014.11.009, 2015.

Cohen, T. J., Nanson, G. C., Jansen, J. D., Jones, B. G., Jacobs, Z., Treble, P., Price, D. M., May, J. H., Smith, A. M., Ayliffe, L. K., and Hellstrom, J. C.: Continental aridification and the vanishing of Australia's megalakes, Geology, 39, 167-170, https://doi.org/10.1130/G31518.1, 2011.

COHMAP Members: Climatic Changes of the Last 18,000 Years: Observations and Model Simulations, Science, 241, 1043-1052, https://doi.org/10.1126/science.241.4869.1043, 1988.

Davies, H.: Quaternary Palaeolimnology of a MexicanCrater Lake, PhD thesis, University of Kingston, Kingston, 1995.

Dickinson, D. R., Yepsen, J. H., and Hales, J. V.: Saturated vapor pressures over Great Salt Lake brines, J. Geophys. Res., 70, 500503, https://doi.org/10.1029/jz070i002p00500, 1965.

Dykoski, C. A., Edwards, R. L., Cheng, H., Yuan, D. X., Cai, Y. J., Zhang, M. L., Lin, Y. S., Qing, J. M., An, Z. S., and Revenaugh, J.: A high-resolution, absolute-dated Holocene and deglacial Asian monsoon record from Dongge Cave, China, Earth Planet. Sc. Lett., 233, 71-86, https://doi.org/10.1016/j.epsl.2005.01.036, 2005.

Editorial Committee of China's Physical Geography, Chinese Academy of Sciences: The Physical Geographical Climate in China, Science Press, Beijing, 1984

Fleitmann, D., Burns, S. J, Mudelsee, M., Neff, U., Kramers, J. D., Mangini, A., and Matter, A.: Holocene Forcing of the Indian Monsoon Recorded in a Stalagmite from Southern Oman, Science, 300, 1737-1739, https://doi.org/10.1126/science.1083130, 2003.

Flückiger, J., Dallenbach, A., Blunier, T., Stauffer, B., Stocker, T. F., Raynaud, D., and Barnola, J.: Variations in atmospheric $\mathrm{N}_{2} \mathrm{O}$ concentration during abrupt climate changes, Science, 285, 227230, https://doi.org/10.1126/science.285.5425.227, 1999.

Flückiger, J., Monnin, E., Stauffer, B., Schwander, J., Stocker, T. F., Chappellaz, J., Raynaud, D., and Barnola, J. M.: Highresolution Holocene $\mathrm{N}_{2} \mathrm{O}$ ice core record and its relationship with $\mathrm{CH}_{4}$ and $\mathrm{CO}_{2}$, Global Biogeochem. Cy., 16, 10-1-10-8, https://doi.org/10.1029/2001GB001417, 2002.

Fontes, J. C., Gasse, F., and Gibert, E.: Holocene environmental changes in Lake Bangong basin (Western Tibet). Part 1: Chronology and stable isotopes of carbonates of a Holocene lacustrine core, Palaeogeogr. Palaeocl., 120, 25-47, https://doi.org/10.1016/0031-0182(95)00032-1, 1996.

Goldsmith, Y., Broecker, W. S., Xu, H., Polissar, P. J., deMenocal, P. B., Porat, N., Lan, J. H., Cheng, P., Zhou, W. J., and An, Z. S.: Northward extent of East Asian monsoon covaries with intensity on orbital and millennial timescales, P. Natl. Acad. Sci. USA, 114, 1817-1821, https://doi.org/10.1073/pnas.1616708114, 2017.

Guo, X. Y.: Holocene climate change documented by lake sediments from Lake Gahai in the monsoonal margin, northwest north, PhD thesis, Lanzhou University, Lanzhou, 2012.

Hart, W. S., Quade, J., Madsen, D. B., Kaufman, D. S., and Oviatt, C. G.: The ${ }^{87} \mathrm{Sr} /{ }^{86} \mathrm{Sr}$ ratios of lacustrine carbonates and lakelevel history of the Bonneville paleolake system, Geol. Soc. Am. Bull., 116, 1107-1119, https://doi.org/10.1130/b25330.1, 2004.
He, F.: Simulating Transient Climate Evolution of the Last Deglaciation with CCSM 3, PhD thesis, University of Wisconsin, Madison, 2011.

Heinecke, L., Mischke, S., Adler, K., Barth, A., Biskaborn, B. K., Plessen, B., Nitze, I., Kuhn, G., Rajabov, I., and Herzschuh, U.: Climatic and limnological changes at Lake Karakul (Tajikistan) during the last $\sim 29$ cal ka, J. Paleolimnol., 58, 317-334, https://doi.org/10.1007/s10933-017-9980-0, 2017.

Herzschuh, U., Cao, X. Y, Laepple, T., Dallmeyer, A., Telford, R. J., Ni, J., Chen, F. H., Kong, Z. C., Liu, G. X., Liu, K. B., Liu, X. Q., Stebich, M., Tang, L. Y., Tian, F., Wang, Y. B., Wischnewski, J., Xu, Q. H., Yan, S., Yang, Z. J., Yu, G., Zhang, Y., Zhao, Y., and Zheng, Z.: Position and orientation of the westerly jet determined Holocene rainfall patterns in China, Nat. Commun., 10, 2376, https://doi.org/10.1038/s41467-019-09866-8, 2019.

Hostetler, S. W. and Bartlein, P. J.: Simulation of lake evaporation with application to modeling lake level variations of HarneyMalheur Lake, Oregon, Water Resour. Res., 26, 2603-2612, https://doi.org/10.1029/WR026i010p02603, 1990.

Hu, C. Y., Henderson, G. M., Huang, J. H., Xie, S. C., Sun, Y., and Johnson, K. R.: Quantification of Holocene Asian monsoon rainfall from spatially separated cave records, Earth Planet. Sc. Lett., 266, 221-232, https://doi.org/10.1016/j.epsl.2007.10.015, 2008.

Huang, X. Z., Chen, F. H., Fan, Y. X., and Yang, M. L.: Dry late-glacial and early Holocene climate in arid central Asia indicated by lithological and palynological evidence from Bosten Lake, China, Quatern. Int., 194, 19-27, https://doi.org/10.1016/j.quaint.2007.10.002, 2009.

Ibarra, D. E., Egger, A., Weaver, K. L., Harris, C. R., and Maher, K.: Rise and fall of late Pleistocene pluvial lakes in response to reduced evaporation and precipitation: Evidence from Lake Surprise, California, Geol. Soc. Am. Bull., 126, 1387-1415, https://doi.org/10.1130/b31014.1, 2014.

Jin, J. H., Cao, X. D., Li, Z. Z., Chen, X. L., Hu, F. G., Xia, J., and Wang, X. L.: Record for climate revolution in aeolian deposit of Nabkhas around the Ebinur Lake, Journal of Desert Research, 33, 1314-1323, 2013.

Kliem, P., Buylaert, J. P., Hahn, A., Mayr, C., Murray, A. S., Ohlendorf, C., Veres, D., Wastegard, S., Zolitschka, B., and the PASADO science team: Magnitude, geomorphic response and climate links of lake level oscillations at Laguna Potrok Aike, Patagonian steppe (Argentina), Quaternary Sci. Rev., 71, 131146, https://doi.org/10.1016/j.quascirev.2012.08.023, 2013.

Konecky, B. L., Russell, J. M., Johnson, T. C., Brown, E. T., Berke, M. A., Werne, J. P., and Huang, Y. S.: Atmospheric circulation patterns during late Pleistocene climate changes at Lake Malawi, Africa, Earth Planet. Sc. Lett., 312, 318-326, https://doi.org/10.1016/j.epsl.2011.10.020, 2011.

Krider, P. R.: Paleoclimatic significance of late Quaternary lacustrine and alluvial stratigraphy, Animas Valley, New Mexico, Quaternary Res., 50, 283-289, https://doi.org/10.1006/qres.1998.1997, 1998.

Lachniet, M. S., Denniston, R. F., Asmerom, Y., and Polyak, V. J.: Orbital control of western north america atmospheric circulation and climate over two glacial cycles, Nat. Commun., 5, 3805, https://doi.org/10.1038/ncomms4805, 2014.

Larsen, D. J., Finkenbinder, M. S., Abbott, M. B., and Ofstun, A. R.: Deglaciation and postglacial environmental changes in 
the Teton Mountain Range recorded at Jenny Lake, Grand Teton National Park, WY, Quaternary Sci. Rev., 138, 62-75, https://doi.org/10.1016/j.quascirev.2016.02.024, 2016.

Lawrence Livermore National Laboratory: ESGF@DOE/LLNL, ESGF, available at: https://esgf-node.llnl.gov/projects/esgf-1lnl/, last access: 6 November 2020.

Lee, M. K., Lee, Y. I., Lim, H. S., Lee, J. I., and Yoon, H. I.: Late Pleistocene-Holocene records from Lake Ulaan, southern Mongolia: implications for east Asian palaeomonsoonal climate changes, J. Quaternary Sci., 28, 370-378, https://doi.org/10.1002/jqs.2626, 2013.

$\mathrm{Li}$, J. J.: The pattern of environmental changes since late Pleistocene in northwestern China, Quaternary Science, 3, 197-204, 1990.

Li, W. L., Wang, K. L., Fu, S. M., and Jiang, H.: The interrelationship between regional westerly index and the water vapor budget in Northwest China, Journal of Glaciology and Geocryology, 30, 28-34, https://doi.org/10.3724/SP.J.1047.2008.00014, 2008.

Li, X. Q., Liu, H. B., Zhao, K. L., Ji, M., and Zhou, X. Y.: Holocene climate and environmental changes reconstructed from elemental geochemistry in the western Hexi Corridor, Acta Anthropologica Sinica, 32, 110-120, 2013.

Li, Y. and Morrill, C.: Multiple factors causing Holocene lakelevel change in monsoonal and arid central Asia as identified by model experiments, Clim. Dynam., 35, 1115-1128, https://doi.org/10.1007/s00382-010-0861-8, 2010.

Li, Y. and Morrill, C.: Lake levels in Asia at the Last Glacial Maximum as indicators of hydrologic sensitivity to greenhouse gas concentrations, Quaternary Sci. Rev., 60, 1-12, https://doi.org/10.1016/j.quascirev.2012.10.045, 2013.

Li, Y., Wang, N. A., Li, Z. L., and Zhang, H. A.: Holocene palynological records and their responses to the controversies of climate system in the Shiyang River drainage basin, Chinese Sci. Bull., 56, 535-546, https://doi.org/10.1007/s11434-010-4277-y, 2011.

Li, Y., Wang, N. A., Li, Z. L., and Zhang, H. A.: Basin-wide Holocene environmental changes in the marginal area of the Asian monsoon, northwest China, Environ. Earth Sci., 65, 203212, https://doi.org/10.1007/s12665-011-1083-z, 2012.

Li, Y., Wang, N. A., Li, Z. L., Zhou, X. H., and Zhang, C. Q.: Climatic and environmental change in Yanchi Lake, Northwest China since the Late Glacial: A comprehensive analysis of lake sediments, J. Geogr. Sci., 23, 932-946, https://doi.org/10.1007/s11442-013-1053-3, 2013.

Li, Y., Zhang, C. Q., Wang, N. A., Han, Q., Zhang, X. Z., Liu, Y., Xu, L. M., and Ye, W. T.: Substantial inorganic carbon sink in closed drainage basins globally, Nat. Geosci., 10, 501-506, https://doi.org/10.1038/ngeo2972, 2017.

Li, Y., Zhang, Y. X., Zhang, X. Z., Ye, W. T., Xu, L. M., Han, Q., Li, Y. C., Liu, H. B., and Peng, S. M.: A continuous simulation of Holocene effective moisture change represented by variability of virtual lake level in East and Central Asia, Sci. China Earth Sci., 63, 1161-1175, https://doi.org/10.1007/s11430-019-9576$\mathrm{x}, 2020$.

Li, Y. F., Zhang, Q. S., and Li, B. Y.: Late Pleistocene Ostracoda from Bangong Lake, Xizang and its palaeogeographic significance, Acta Micropalaeontologica Sinica, 8, 57-64, 1991.

Licciardi, J. M., Clark, P. U., Jenson, J. W., and Macayeal, D. R.: Deglaciation of a soft-bedded Laurentide ice sheet, Quaternary Sci. Rev., 17, 427-448, https://doi.org/10.1016/s02773791(97)00044-9, 1998.
Linderholm, H. W., and Bräeuning, A.: Comparison of highresolution climate proxies from the Tibetan plateau and Scandinavia during the last millennium, Quatern. Int., 154, 141-148, https://doi.org/10.1016/j.quaint.2006.02.010, 2006.

Liu, X. Q., Dong, H. L., Rech, J. A., Matsumoto, R., Yang, B., and Wang, Y. B.: Evolution of Chaka Salt Lake in NW China in response to climatic change during the Latest Pleistocene-Holocene, Quaternary Sci. Rev., 27, 867-879, https://doi.org/10.1016/j.quascirev.2007.12.006, 2008a.

Liu, X. Q., Herzschuh, U., Shen, J., Jiang, Q. F., and Xiao, X. Y.: Holocene environmental and climatic changes inferred from $\mathrm{Wu}-$ lungu Lake in northern Xinjiang, China, Quaternary Res., 70, 412-425, https://doi.org/10.1016/j.yqres.2008.06.005, 2008b.

Louderback, L. A. and Rhode, D. E.: 15,000 Years of vegetation change in the Bonneville basin: the Blue Lake pollen record, Quaternary Sci. Rev., 28, 308-326, https://doi.org/10.1016/j.quascirev.2008.09.027, 2009.

Lowry, D. P. and Morrill, C.: Is the Last Glacial Maximum a reverse analog for future hydroclimate changes in the Americas? Clim. Dynam., 52, 4407-4427, https://doi.org/10.1007/s00382018-4385-y, 2019.

Lu, Y. B., An, C. B., Zhao, J. J.: An isotopic study on water system of Lake Barkol and its implication for Holocene climate dynamics in arid central Asia, Environ. Earth Sci., 73, 1377-1383, https://doi.org/10.1007/s12665-014-3492-2, 2015.

Lyle, M., Heusser, L., Ravelo, A. C., Yamamoto, M., Barron, J. A., Diffenbaugh, N. S., Herbert, T. D., and Andreasen, D.: Out of the Tropics: The Pacific, Great Basin Lakes, and Late Pleistocene Water Cycle in the Western United States, Science, 337, 16291633, https://doi.org/10.1126/science.1218390, 2012.

Ma, Z. B., Wang, Z. H., Liu, J. Q., Yuan, B. Y., Xiao, J. L., and Zhang, G. P.: U-series chronology of sediments associated with Late Quaternary fluctuations, Balikun Lake, northwestern China, Quatern. Int., 121, 89-98, https://doi.org/10.1016/S10406182(04)00035-7, 2004.

Madsen, D. B., Ma, H. Z., Rhode, D., Brantingham, P. J., and Forman, S. L.: Age constraints on the late Quaternary evolution of Qinghai Lake, Tibetan Plateau, Quaternary Res., 69, 316-325, https://doi.org/10.1016/j.yqres.2007.10.013, 2008.

Metcalfe, S., Say, A., Black, S., McCulloch, R. D., and O'Hara, S.: Wet conditions during the last glaciation in the Chihuahuan Desert, Alta Babicora Basin, Mexico, Quaternary Res., 57, 91101, https://doi.org/10.1006/qres.2001.2292, 2002.

Mischke, S. and Zhang, C.: Ostracod distribution in Ulungur Lake (Xinjiang, China) and a reassessed Holocene record, Ecol. Res., 26, 133-145, https://doi.org/10.1007/s11284-010-0768-1, 2011.

Monnin, E., Steig, E. J., Siegenthaler, U., Kawamura, K., Schwander, J., Stauffer, B., Stocker, T. F., Morse, D. L., Barnola, J. M., Bellier, B., Raynaud, D., and Fisher, H.: Evidence for substantial accumulation rate variability in Antarctica during the Holocene, through synchronization of $\mathrm{CO}_{2}$ in the Taylor Dome, Dome C and DML ice cores, Earth Planet. Sc. Lett., 224, 45-54, https://doi.org/10.1016/j.eps1.2004.05.007, 2004.

Moreno, P. I. and León, A. L.: Abrupt vegetation changes during the last glacial to Holocene transition in mid-latitude South America, J. Quaternary Sci., 18, 787-800, https://doi.org/10.1002/jqs.801, 2003. 
Morrill, C.: The influence of Asian summer monsoon variability on the water balance of a Tibetan lake, J. Paleolimnol., 32, 273-286, https://doi.org/10.1023/b:jopl.0000042918.18798.cb, 2004.

Morrill, C., Small, E. E., and Sloan, L. C.: Modeling orbital forcing of lake level change: Lake Gosiute (Eocene), North America, Global Planet. Change, 29, 57-76, https://doi.org/10.1016/s0921-8181(00)00084-9, 2001.

Mumma, S. A., Whitlock, C., and Pierce, K.: A 28,000 year history of vegetation and climate from Lower Red Rock Lake, Centennial Valley, Southwestern Montana, USA, Palaeogeogr. Palaeocl., 326-328, 30-41, https://doi.org/10.1016/j.palaeo.2012.01.036, 2012.

Nagashima, K., Tada, R., and Toyoda, S.: Westerly jetEast Asian summer monsoon connection during the Holocene, Geochem. Geophy. Geosy., 14, 5041-5053, https://doi.org/10.1002/2013GC004931, 2013.

NCAR: TraCE-21ka dataset, Climate Data Gateway, available at: https://www.earthsystemgrid.org/project/trace.html, last access: 6 November 2020.

Oster, J. L., Ibarra, D. E., Winnick, M. J., and Maher, K.: Steering of westerly storms over western North America at the Last Glacial Maximum, Nat. Geosci., 8, 201-205, https://doi.org/10.1038/ngeo2365, 2015.

Öğretmen, N. and Çağatay, M. N.: Paleoenvironmental Changes in Lake Van During the Last Glacial-Holocene, EGU, 2012.

Oviatt, C. G.: Chronology of Lake Bonneville, 30,000 to $10,000 \mathrm{yr}$ B.P., Quaternary Sci. Rev., 110, 166-171, https://doi.org/10.1016/j.quascirev.2014.12.016, 2015.

Peltier, W. R.: Global glacial isostasy and the surface of the ice-age Earth: The ICE-5G (VM2) model and GRACE, Annu. Rev. Earth Pl. Sc., 32, 111-149, https://doi.org/10.1146/annurev.earth.32.082503.144359, 2004.

Pribyl, P. and Shuman, B. N.: A computational approach to Quaternary lake-level reconstruction applied in the central Rocky Mountains, Wyoming, USA, Quaternary Res., 82, 249-259, https://doi.org/10.1016/j.yqres.2014.01.012, 2014.

Qin, B. Q. and Yu, G.: Implications of lake level fluctuations at $6 \mathrm{ka}$ and $18 \mathrm{ka}$ in mainland Asia, Global Planet. Change, 18, 59-72, https://doi.org/10.1016/S0921-8181(98)00036-8, 1998.

Qin, B. Q., Harrison, P., Yu, G., Tarasov, P. E. T., and Damnati, B.: The geological evidence of the global moisture condition changes since the last glacial maximum: the construction of global lake status database \& the synthesis in the large spatio-temporal scale, Journal of Lake Sciences, 9, 203-210, https://doi.org/10.1145/2441776.2441923, 1997.

Quade, J. and Broecker, W. S.: Dryland hydrology in a warmer world: Lessons from the Last Glacial period, Eur. Phys. J-Spec. Top., 176, 21-36, https://doi.org/10.1140/epjst/e2009-01146-y, 2009.

Rambeau, C. M. C.: Palaeoenvironmental reconstruction in the southern levant: synthesis, challenges, recent developments and perspectives, Philos. T. R. Soc. A, 368, 5225-5248, https://doi.org/10.1098/rsta.2010.0190, 2010.

Rasmussen, S. O., Andersen, K. K., Svensson, A. M., Steffensen, J. P., Vinther, B., Clausen, H. B., Siggaard-Andersen, M. L., Johnsen, S. J., Larsen, L. B., Dahl-Jensen, D., Bigler, M., Röthlisberger, R., Fischer, H., Goto-Azuma, K., Hansson, M. E., and Ruth, U.: A new Greenland ice core chronology for the last glacial termination, J. Geophys. Res.-Atmos., 111, 1-15, https://doi.org/10.1029/2005JD006079, 2006.

Rhodes, T. E., Gasse, F., Lin, R. F., Fontes, J. C., Wei, K. W., Bertrand, P., Gibert, E., Mélières, F., Tucholka, P., Wang, Z. X., and Cheng, Z. Y.: A Late Pleistocene-Holocene lacustrine record from Lake Manas, Zunggar (northern Xinjiang, western China), Palaeogeogr. Palaeocl., 120, 105-121, https://doi.org/10.1016/0031-0182(95)00037-2, 1996.

Riedel, F., Henderson, A. C. G., Heußner, K. U., Kaufmann, G., Kossler, A., Leipe, C., Shemang, E., and Taft, L.: Dynamics of a Kalahari long-lived mega-lake system: hydromorphological and limnological changes in the Makgadikgadi Basin (Botswana) during the terminal $50 \mathrm{ka}$, Hydrobiologia, 739, 2553, https://doi.org/10.1007/s10750-013-1647-x, 2014.

Rossit, C., Laura, P. A. A., Bambill, D., Fontes, J. C., Gasse, F., and Gibert, E.: Holocene environmental changes in Lake Bangong basin (Western Tibet). Part 1: Chronology and stable isotopes of carbonates of a Holocene lacustrine core, Palaeogeogr. Palaeocl., 120, 25-47, https://doi.org/10.1016/00310182(95)00032-1, 1996.

Rowe, H. D., Dunbar, R. B., Mucciarone, D. A., Seltzer, G. O., Baker, P. A., and Fritz, S: Insolation, moisture balance and climatic change on the South American Altiplano since the last glacial maximum, Climatic Change, 52, 175-199, https://doi.org/10.1023/a:1013090912424, 2002.

Shen, J., Liu, X. Q., Wang, S. M., and Matsumoto, R.: Palaeoclimatic changes in the Qinghai Lake area during the last 18,000 years, Quatern. Int., 136, 131-140, https://doi.org/10.1016/j.quaint.2004.11.014, 2005.

Street, F. A. and Grove, A. T.: Global maps of lake-level fluctuations since $30000 \mathrm{yr}$ B.P., Quaternary Res., 12, 83-118, https://doi.org/10.1016/0033-5894(79)90092-9, 1979.

Sun, A. Z., Feng, Z. D., Ran, M., and Zhang, C. J.: Pollen-recorded bioclimatic variations of the last $\sim 22,600$ years retrieved from Achit Nuur core in the western Mongolian Plateau, Quatern. Int., 311, 36-43, https://doi.org/10.1016/j.quaint.2013.07.002, 2013.

Voigt, I., Chiessi, C. M., Prange, M., Mulitza, S., Groeneveld, J., Varma, V., and Henrich, R.: Holocene shifts of the Southern Westerlies across the South Atlantic, Paleoceanography, 30, 39 51, https://doi.org/10.1002/2014pa002677, 2015.

Wang, P. X.: Global monsoon in a geological perspective, Chinese Sci. Bull., 54, 1113-1136, https://doi.org/10.1007/s11434-0090169-4, 2009.

Wang, R. L., Scarpitta, S. C., Zhang, S. C., and Zheng, M. P.: Later Pleistocene/Holocene climate conditions of Qinghai-Xizhang Plateau (Tibet) based on carbon and oxygen stable isotopes of Zabuye Lake sediments, Earth Planet. Sc. Lett., 203, 461-477, https://doi.org/10.1016/s0012-821x(02)00829-4, 2002.

Wang, Y. B., Benjamin, B., Dörthe, H., Liu, X. Q., Anne, D., and Ulrike, H.: Coherent tropical-subtropical Holocene see-saw moisture patterns in the Eastern Hemisphere monsoon systems, Quaternary Sci. Rev., 169, 231-242, https://doi.org/10.1016/j.quascirev.2017.06.006, 2017.

Wang, Y. J., Cheng, H., Edwards, R. L., Kong, X. X. G., Shao, X. H., Chen, S. T., Wu, J. Y., Jiang, X. Y., Wang, X. F., and An, Z. S.: Millennial- and orbital-scale changes in the East Asian monsoon over the past 224,000 years, Nature, 451, 1090-1093, https://doi.org/10.1038/nature06692, 2008. 
Waters, M. R.: Late Quaternary lacustrine history and paleoclimatic significance of pluvial Lake Cochise, southeastern Arizona, Quaternary Res., 32, 1-11, https://doi.org/10.1016/00335894(89)90027-6, 1989.

Witt, R., Günther, F., Lauterbach, S., Kasper, T., Mäusbacher, R., Yao, T. D., and Gleixner, G.: Biogeochemical evidence for freshwater periods during the Last Glacial Maximum recorded in lake sediments from Nam Co, south-central Tibetan Plateau, J. Paleolimnol., 55, 67-82, https://doi.org/10.1007/s10933-015-9863-1, 2016.

Wu, D.: Changes of regional hydrology and summer monsoon since the Last Glacial Maximum recorded by Dalianhai Lake, Tibetan Plateau, PhD thesis, Lanzhou University, Lanzhou, 2017.

Wu, H. B. and Guo, Z. T.: Evolution and drought events in arid region of northern China since the Last Glacial Maximum, Quaternary Science, 20, 548-558, 2000.

Wu, J. L., Wang, S. M., and Wu, Y. H.: The Holocene sedimental characteristic and paleoclimatic evolution of Ebinur lake, Xinjiang, Chinese Geogr. Sci., 6, 78-88, https://doi.org/10.1007/s11769-996-0038-x, 1995.

Wu, Y. H., Lücke, A., Wünnemann, B., Li, S. J., and Wang, S. M.: Holocene climate change in the Central Tibetan Plateau inferred by lacustrine sediment geochemical records, Sci. China Earth Sci., 50, 1548-1555, https://doi.org/10.1007/s11430-007-0113$\mathrm{x}, 2007$.

Wünnemann, B., Mischke, S., and Chen, F. H.: A Holocene sedimentary record from Bosten Lake, China, Palaeogeogr. Palaeocl., 234, 223-238, https://doi.org/10.1016/j.palaeo.2005.10.016, 2006.

WWF: HydroBASINS Version 1.0, HydroSHEDS, available at: https://www.hydrosheds.org/page/hydrobasins, last access: 6 November 2020.

Xue, B. and Yu, G.: Changes of Atmospheric Circulation since the Last Interstadial as Indicated by the Lake-status Record in China, Acta Geol. Sin.-Engl., 74, 836-845, https://doi.org/10.1111/j.1755-6724.2000.tb00499.x, 2000.

Xue, J. B. and Zhong, W.: Holocene climate variation denoted by Barkol Lake sediments in northeastern Xinjiang and its possible linkage to the high and low latitude climates, Sci. China Earth Sci., 54, 603-614, https://doi.org/10.1007/s11430-010-4111-z, 2011.

Yan, D. and Wünnemann, B.: Late Quaternary water depth changes in Hala Lake, northeastern Tibetan Plateau, derived from ostracod assemblages and sediment properties in multiple sediment records, Quaternary Sci. Rev., 95, 95-114, https://doi.org/10.1016/j.quascirev.2014.04.030, 2014.
Yan, S., Mu, G. J., and Xu, Y. Q.: Quaternary environmental evolution of the Lop Nur region, NW China, Acta Micropalaeontologica Sinica, 17, 165-169, 2000.

Yu, G., Xue, B., Wang, S. M., and Liu, J.: Chinese lakes records and the climate significance during Last Glacial Maximum, Chinese Sci. Bull., 45, 250-255, 2000.

Yuan, D., Cheng, H. Y., Edwards, R. L., Dykoski, C. A., Kelly, M. J., and Zhang, M.: Timing, Duration, and Transitions of the Last Interglacial Asian Monsoon, Science, 304, 575-578, https://doi.org/10.1126/science.1091220, 2004.

Zhang, C. J., Chen, F. H., Shang, H. M., and Cao, J.: The paleoenvironmental significance of organic carbon isotope in lacustrine sediments in the arid China: An example from Sanjiaocheng palaeolake in Minqin, Quaternary Science, 24, 88-94, 2004.

Zhang, H. C., Peng, J. L., Ma, Y. Z., Chen, G. J., Feng, Z. D., Li, B., Fan, H. F., Chang, F. Q., Lei, G. L., and Wünnemann, B.: Late Quaternary palaeolake levels in Tengger Desert, NW China, Palaeogeogr. Palaeocl., 211, 45-58, https://doi.org/10.1016/j.palaeo.2004.04.006, 2004.

Zhao, C., Yu, Z. C., Zhao, Y., Ito, E., Kodama, K. P., and Chen, F. H.: Holocene millennial-scale climate variations documented by multiple lake-level proxies in sediment cores from Hurleg Lake, Northwest China, J. Paleolimnol., 44, 995-1008, https://doi.org/10.1007/s10933-010-9469-6, 2010.

Zhao, L. Y., Lu, H. Y., Zhang, E. L., Wang, X. Y., Yi, S. W., Chen, Y. Y., Zhang, H. Y., and Wu, B.: Lake-level and paleoenvironment variation in Yitang Lake (northwestern China) during the past $23 \mathrm{ka}$ revealed by stable carbon isotopic composition of organic matter of lacustrine sediments, Quaternary Science, 35, 172-179, 2015.

Zhou, T. J., Yu, R. C., Li, H. M., and Wang, B.: Ocean Forcing to Changes in Global Monsoon Precipitation over the Recent Half-Century, J. Climate, 21, 3833-3852, https://doi.org/10.1175/2008jcli2067.1, 2008.

Zhu, L. P., Zhen, X. L., Wang, J. B., Lu, H. Y., Xie, M. P., Kitagawa, H., and Possnert, G.: A 30, 000-year record of environmental changes inferred from Lake Chen Co, southern Tibet, J. Paleolimnol., 42, 343-358, https://doi.org/10.1007/s10933-0089280-9, 2009. 